\title{
Existentialist Echoes in Harold Pinter's Early Poetry
}

Yousef Bakhshizadeh Gashti*

Chabahar Maritime University, Iran

Corresponding Author: Yousef Bakhshizadeh Gashti, E-mail: yousefbakhshi@cmu.ac.ir

\section{ARTICLE INFO}

Article history

Received: January 01, 2018

Accepted: March 07, 2018

Published: July 01, 2018

Volume: 7 Issue: 4

Advance access: May 2018

Conflicts of interest: None

Funding: None

\begin{abstract}
This paper has attempted to investigate the absurdist voices in Harold Pinter's selected poems written from 1951to1953. These poems belonging to his early phase of writing as the poet deals with the major obsessions of post-Modern man depicting his anxiety of identity aggravated by his existential condition. Pinter's early poetry characterizes him as an absurdist poet and expresses his world view through distinctive images and tones. The selected poems appear to be a blending of his absurdist insights with his poetic art. His early poems predominantly portray existential anxiety, absurdity and pessimism. The study seeks to reflect on Pinter as a practitioner of the 'Literature of the Absurd' who tries to depict how different people act and react when they confront different aspects of absurdity and existential dilemma.
\end{abstract}

Key words: Harold Pinter, Early Poetry, Absurdist Insight, Existential Dilemma

\section{INTRODUCTION}

Pinter belongs to the postwar era that witnessed the emergence of the avant-garde theatre in Britain and Europe. He grew up with a generation that experienced the absurdist movement pervading most of the $20^{\text {th }}$ century intellectual world and literary works. 'The Theatre of the Absurd', a term coined by Martin Esslin to describe post- War Theater, developed on account of various socio-philosophical reasons: technological advances, religious uncertainty, the fundamental need for subjectivity and the dominance of existentialism as a philosophic thought of that period. These reasons eventually led the dominant trends to a new era known as post- modernity. The characteristic features of post-modernism such as the feelings of individual and social disintegration, insecurity, dominance and subservience, scepticism about religions, and the politics of space are all portrayed through the content and form in Pinter's plays and poetry.

While researching several full-length sources written on Pinter oeuvres, the researcher could not find any critic who had contributed a single full-length work exclusively written on his poetry. There are very few critics who have discussed Pinter's poems-- and that too limited to a couple of pages in their researches which are mainly written on his plays. Knowing that Pinter initiallycomposed poems and then began to write plays, the researcher believes the appreciation of his poems will provide the scholars with a better understanding of his plays.

Pinter's social background plays an important role in the creation of his literary output. Even as a school student, Pinter used poetry to reveal his feelings of insecurity and conflict; and as a young man he tried to express his doubt and uncertainty about his own identity (Billington 8). In fact, loss of identity and the feeling of isolation have been recurrent themes in his poems especially those written from 1951 to 1953 . This vision is depicted in his poem "A Glass at Midnight," which echoes the inner contemplation and anxiety of a baffled and forsaken young man. Thus, the poem reads as, "Miles of the poles in the room's corners.../Worlds within this box/I hold the cipher of the voided world."

Pinter was only seventeen years of age when he sensed loneliness and insensitivity of life and decided to fill such irrational and insensitive emptiness by writing poems. He employs innovative images in order to reflect his hesitations and uncertainty about the sources of fear and absurdity. His poem "A Glass at Midnight" clearly mirrors such absurdity as, "The religion that emerges on the wall/I let the glass drop. A bridge falls...."

Pinter is considered to be the last generation of the absurdist writers. Martin Esslin notes that "for Pinter, there is no contradiction between the desire for realism and the basic absurdity of the situations that inspire him" (Theatre of the Absurd 272). Thus, some critics have tried to label Pinter a mere 'absurdist' but some others have attempted to prove that his works differ in some respects from those written by the other absurd dramatists such as Beckett, Ionesco, Adamov and Genet. As regards the major characteristics of his works, Joseph Hynes on his online article refers to some of the terms which are attributed to Pinter by critics -terms such as existentialist, absurdist, and anti- humanistic, but Hynes believes that a critic should go beyond these terms if he is going to offer a good interpretation of Pinter's works. ("Pinter and Morality") 
Pinter has read a lot from notable writers like Joyce, Kafka, Beckett, Ionesco and Hemingway, and Roy believes their influence on him is well understood in his works (British Drama since Shaw 237). In an interview with Bensky,Pinter states that"I have been influenced personally by everyone I've ever read - and I read all the time but none of these writers particularly influenced my writing. Beckett and Kafka stayed with me the most. My world is still bound up by other writers - this is one of the best things in it" (qtd. in Ganz 22). Brown, on the other hand, offers a different view towards Pinter's canon. He claims that Pinter's critics face a kind of eclectic scholarship rather than of creation, because he might have read all of the major sources such as Ionesco, Genet, Beckett, Albee and many other writers (Modern British Dramatists 197-98). Critics had also predicted Pinter's unique position in the world of modern drama. Merritt considered him as "... a canonical playwright, on whose drama a huge number of researches has been done" (Pinter in Play 65). Gale expressed that Pinter was unquestionably "the major force in the contemporary English- speaking theatre." (Butter's Going Up 278)

Pinter had experienced some horrible events which seem to have affected his life and works that can be traced in his drama and poetry. He was only a child when was taken away from his family by then British government to a safer place during Nazi bombardment of London. It took a few years for him to rejoin his family. The continual threat of fascist gangs against him as a member of the Jewish community in the East End of London gradually affected his sensitive soul. His love of acting, however, made him leave London for Ireland to act in the theatrical rehearsal. He was only seventeen years old and his tour in Andrew McMaster's amateur travelling company took about two years. This was a turning point during which he could express the feelings of his tortured soul. In an interview with Gussow, Pinter says that he toured Ireland with McMaster for two years in the early 1950s and he advertised in the stage for actors for a Shakespeare tour of the country (Conversation with Pinter 110). The influence of this tour in Ireland with all its natural landscapes together with his departure from London and his family had a strong impact on his emotions and sentiments and also on his literary output. These feelings and his artistic sensibility can be tracked alike in his poetry and prose such as "The Islands of Aran", "The Queen of All the Fairies", "Kullus," and "Episode". The entire two years in Ireland was a period of self-realization to ponder over his self and emotions and enliven the images of Ireland as a source of brushing up his creativity. It was during this tour that Pinter began to read the works of Samuel Beckett, one of the leading dramatists of absurd literature. Prentice quotes Bakewell's interview with Pinter as "I was one of the very first people... who came across Beckett. I was in Ireland... and I picked up a copy of "Irish Writing", a little magazine. I must admit. And there was a piece of Beckett's, a fragment from Watt...." (Pinter Ethic xxxvii)

The poem, "The Islands of Aran," literally depicts natural sceneries of Ireland which capture the gaze of any viewers by the spectacular rocky islands, "Aran like three black whales/Humped on the water." Metaphorically, the poem de- lineates something beyond its literal meanings. It may tend to depict the myth of Sisyphus in different ways. The poem will be discussed in detail in this article.

\section{AIMS AND SIGNIFICANCE OF THE STUDY}

The main objective of this study is to explore how Pinter has attempted to depict the nature of absurdity, and how different people react to the absurd situations they confront. This investigation introduces Pinter as a practitioner of the absurd literature and as an existentialist writer. This research will help the readers to know more about the relationship between Pinter's art and his intellectual and philosophical insight.

\section{RESEARCH QUESTIONS}

This research is in pursuit of finding the answers to the following questions:

1. Does Pinter's early poetry bear the absurdist codes?

2. Do the social and intellectual events of the time have any effects on Pinter's poetic canon?

\section{RESEARCH METHOD}

According to the theory of the absurdist undertones of Pinter's early poems, this study has chosen a number of his poems composed in early 1950s which are thematically different from his later collection especially those written after 1980.Thus, the themes of the poems under discussion are linked with the theories of the absurd articulated by Albert Camus and other existentialist thinkers. In addition to the selected poems, the researcher has also referred to Pinter's interviews, speeches and the critical sources in order to support the main objectives and the topic of the study. Almost all of these poems are included in a volume entitled Poems and Prose 1949-1977 by Harold Pinter.

\section{DISCUSSION}

Pinter's early poems express the themes of absurdity and existential predicament of man. These poems are even more straightforward in their embodiment of the absurdist insights than his first novel,The Dwarfs. They highlight the poet's view of identity as it changes, but at the same time they emphasize the agonizing need of discovering and accepting different aspects of one's identity, of experiencing an almost Jungian integration that requires a recognition of a power drive comparable to one defined by Adler and some other psychologists, and eventually of facing death as Camus suggests. Pinter's absurdist poems more evidently than his later poems persuade the readers to know the 'self,' and to get informed about 'death' though it may be adifficult undertaking to do. These poems depict the absurdist discipline that man's nobleness depends on his struggle with full awareness that death makes that struggle absurd and without any gains. Besides, his absurd poems tend to express that such aconsciousness which is painfully attained will ultimately result in freedom, vital revolt and a restricted form of joy. Freedom "is not primarily the power to choose. It is our capacity to 
understand the world and ourselves and to express this understanding in words and deeds". (Arcilla 17)

Much like albert Camus', Pinter's existentialism is a strategy to revolt against forces hindering man from freedom, decision and action. Both writers create a meaningless world wherein man has to create sense and value. The works of these two writers encourage the readers that life is worth running the risk of revolting against any forcemaking it meaningless; revolt against the notion of suicide, or any socio-philosophical obligations. Camus proposes Galileo's example to illustrate the notion that nobody dies for the ontological disagreement. Thus, he statesthat"Galileo, who held a scientific truth of great importance, abjured it with the greatest ease as soon as it endangered his life. In a certain sense, he did right because the truth was not worth the stake" (Myth of Sisyphus 2). It is perceived that both Camus and Pinter juxtapose revolt with logic in order that man should not deviate from the true path of resistance and revolt.

Camus's notion of Sisyphus comes from a mythological Sisyphus, who was condemned to perpetual punishment due to his attempt to deceive first Death and then Hades, the Lord of the underworld, so that he could escape his inevitable demise. Sisyphus was blinded and sentenced to roll a giant boulder continually up to a mountain to the peak. However, he would never be able to stop his effort as the boulder would roll back down the mountain into the valley. Thus, Camus questions suicide and alternatives to it. He also questions the value of life through this myth by using this as a metaphor for life in his essay published in1942 in France. Camus indicates the meaninglessness of life by saying that life has no value except the ones created by us. Thus, man's efforts are perceived as pointless, absurd as life itself. But Camus appreciates Sisyphus's resistance to submission and his continual efforts to overcome the imposition of despicable fate. In the same way, Pinter's charactersare in a state of perpetual revolt. His characters involve in perpetual fight against different sources of power in his drama. His powerless characters constantlyreject being submissive by the authoritarian agents. In his absurdist poems we find parallelism between Pinter's speakers or personae and Camus's mythological Sisyphus.

Pinter's absurdist poems tend to admire the constant struggle of the decent and principled man with his vision of himself and his world. Furthermore, these poems stress on man's continual struggle and that his happiness, achievements and nobleness may not be acquired without perpetual pain and suffering. This existentialist view can be associated with Camus's embodiment of Sisyphus. In that case, life is an arena of war for Sisyphus and accordingly man should be conscious of one's environment and existence. In view of that, Camus statesthat"Conscious men have been seen to fulfill their task amid the most stupid of wars without considering themselves in contradiction" (Myth of Sisyphus 60). In Pinter's collection of absurd poems, most of the time man may not endure such pain and may retreat from the struggle instead of the action of revolt and freedom. In that case,man may turn away from his main goal of preserving his nobility through continual straggle to find a way to evade the absurdity and to gain his freedom as an individual. Hence as we notice from Camus's vision, instead of struggling to consolidate his position, man escapes the arena and eventually resorts to depression or suicide. The absurdity of suicide, as Deanna Rodriguez quotes Camus "is a conflict between the human tendency to seek inherent value and meaning in life and the human inability to find any, and on what leads a man to think about suicide and ultimately how one can make the decision that life is not worth living anymore." (Rodriguez)

Regarding the concept of absurdity, some of Pinter's poems ask for recognition of the absurdity, expecting a positive reaction from the readers. Based upon the themes of his absurd poems, one can come across a three stage development which is generally comparable to Camus's idea for recognition of the absurd as well as man's response to that realization. The first group ofthese poemsembodies a self-realization of the inactive conditionof man's life; these poems also represent the meaningless actionand man's knowledge of death and its consequences. Next group includes poems slightly resembling Camus's revolt or as Esslin puts it "theimpendence of horrifying fate, without any submission to it" (Theatre of the Absurd 23). Pinter, meanwhile, calls such revolt 'fury' which emerges out of the movement toward anxiety and death. Finally, the third group of these poems expresses direct movement of the absurdist attitude to Camus's "freedom," and "decision". This kind of view which is shared by most of the existentialists comes from Danish philosopher and theologian Kierkegaard's belief in the 'freedom to choose' as both positive and negative force. He has extensively written about "the nature of human character and impetus, the concept of individual freedom of choice, and the rejection of religion and social conventions that engulf the individual consciousness and prevent real choice" (Thorne 243).Esslin discusses Camus's views that freedom emerges from awareness of death and the absurd world that it creates, from the resulting denial of purpose and meaning of the future (Theatre of the Absurd390-91). This freedom persuades man to do his best to confront more experiences of life than retreat from life's adversities or absurdity. Accordingly, Pinter urges his readers to preserve an absurdist viewpoint and, as one of his poems describes it, "to walk the tight rope" which means to keep revolting and reject surrendering to fate or any kind of force. Thus, some critics have been unable to realize such absurdist optimism emerging from the awareness of death in Pinter's poems. Such an attitude involves two interpretations. The first one is the recognition of speaker's voice, but it is not an easy task to determine this voice in Pinter's works because it needs more concentration to find out. Such a voice sometimes becomes more complicated because thematically some characters may speak for the personae of poems or for Pinter himself. The speaker's statement in Pinter's poem, "You in the Night", Ruth's account of the potential importance of movement and her speech in The Homecoming, and Len's speech about identity in The Dwarfs are all good examples to support the above analysis. The second interpretation is that absurdist theme of Pinter's poetry reveals itself in his early dramatic works such as The Room, The Birthday Party, The Caretaker and The Dumbwaiter. In his early plays, as Richard Arrandale states that "We are confronted with potential 
absurdity of our lives as we try to create meaning....We are also confronted with the way in which we try to cover up such inadequacies and are not allowed to get away with it." (Modern Theology 494)

Like many other absurdist-existentialist writers, Pinter believes that we cannot deny the absurdity of life, but at the same time he attempts to portray those people who do not want to challenge the absurdity while simply trying to escape confronting the absurd world. Thus, Pinter persuades people to respond confidently to the absurdity and challenge life's adversities. His early poems and his novel The Dwarfs are of this kind, depicting the same absurdist environment and the sheer impossibility of escaping it, but the readers are motivated not to play passive role while confronting the absurdity. Quite contrary to Samuel Beckett's characters, Pinter's people are more assertive even though they are powerless or being in absurd condition.

Although the standard and the nature of Pinter's early poems differ extensively from each other, most of them are short and only a few appear to be long. Some of them do not have any particular discipline but Esslin observes that even these weaker poems reflect a lavishness which reminds him of Dylan Thomas (Theatre of the Absurd 375). Pinter's poems sometimes echo a negative attraction with queer words and obscure intentions. In much of his good poems he has a strong control and command over language and poetic qualities. There is a love for unusual and archaic words in Pinter's early poems ('Aloodlit empires', 'Palsied stomacher', 'necromantic cauldron of crosses') but, as Billingtonpoints out in Pinter's Website, 'the imagery is strong and haunting; it betrays the author's grasp of the poetic quality of the situations his imagination thrusts upon him. For these poems are clearly written in a state of obsession with words, under the spell of an irresistible impulse" (Billington). Most of these poems, however, are intricate and intellectualized. These poems, in spite of the diversity of styles and techniques, display a consistent world view on man's condition, freedom, assertiveness and revolt. In addition to the above themes with absurdist overtones, his early poems also attempt to explore the themes of menace, unexpected violence, and intrusion.

Pinter portrays his hard times when he acted in performance in Ireland but he welcomes the hardship of life in exchange for his artistic satisfaction and his love for acting. In his poem "The New Year in Midlands" he writes, "..., the power and the blood, and here am I/straddled, exile always in one Whitbread Ale town." Another poem, "The Second Visit", also reveals that the poet is delighted with acting and performing, and he marks the stage as the spell and magic of the world as "Like an actor in this nocturnal sink/The strip of lip is toothed away/And flats and curtains canter down." As a young actor, Pinter attempts to express the ordeal of bitter times and condition filled with a sense of frustration and despair in "The Drama in April": "The articles and props in the rain/Are the ash of house/The grave unnumbered stones in the green". His poem, "The Islands of Aran" portrays the islands located north of the North Channel. This biggest island is surrounded by several smaller ones. In south, the islands lead to the cliffs which are more than one hundred feet higher than sea level. As the poet contemplates over the heavy surf around Aran Islands, his inner insight of that natural landscape emerges and he artistically associates the islands with man's experiences and his struggles with life's hardships. On the surface, "The Islands of Aran" is a nature poem reminiscent of the romantic world expressing private emotion, separation, and solitude because the poem ends with separation of the lovers, "Then Aran with its dreary gates locked/Its back toothed traders/Aran the widower/Aran with no legs."

In reality, the poem portrays pessimistic accounts of the Islands of Aranthrough the images such as "Aran without gain/Man in mourning thumped to losses." As the poem progresses, the events happening around the islands become a sheer extended metaphor for the sufferings and infliction of pain and agony of man. Hence, the poet attempts to associate the islands with his own persona in particular, and to other human beings in general. As a result, the poet signifies the turbulent condition and the restlessfeeling of his inwardsphere. He sorrowfully observes the islands from the cliffs and he, meanwhile, feels he is entrapped by the darkness and confinement, "With its bleak gates locked." Most of the objects and images of this poem deal with bleak and dire pessimism such as "Three black whales," "bleak gates," and"Aran...thumped to losses." The blackness of the Islands of Aran and the bleak atmosphere of the scenery evoke images associated with 'death' and destruction. The inability of "the whales to move" supports the evocative image of absurdity and death. In order to link the "Islands of Aran" to uncertainty and insecure condition of man, the poet uses the technique of 'personification' for the islands "Aran is a widower with no legs," "With a Connemara's head," "mourning clothes," and "Aran makes tough bargains." In his personification of the islands, the poet endeavors to reflect the idea that man lives in a world devoid of any real goal, that he is baffled in an insecure and dreary world. The islands are isolated from "The traders" and no ship can ever harbor there. Metaphorically, as the cliffs of the islands are subjected to horrible pounding of the waves, so is man susceptible to the threats, insecurities and losses of the world. Lastly, the unavoidability of Aran's anguish and its confrontation with dreadful pounding of the sea imply man's pain, anxiety and suffering in an absurd and unpredictable world.

From the stand point of the absurdist interpretation of the above poem, the resistance of the islands against the powerful waves of the sea metaphorically envisages the revolt of man against the absurdity of life. In spite of all destructive pounding, the islands "stares out the waves" and ready to face up any risk instead of submission to the waves. This kind of interpretationsuggests Sisyphean refusal to surrender him to the overpowering fate. The approach of refusing submission to any power agent or force in a ruthless world is also a recurringmotif in most of Pinter's plays.

There are also some more poems that underline the reality of man's condition which can eventually result in the awareness of the absurdity of life. While portraying absurdity, these poems are inclined to accentuate the problem of identity as a frequent theme in Post- War literature of the twentieth century.The poem "Idyll," mainly focuses on the female identity.The poem "Idyll," illustrates the absurdity and desperate condition of a woman living in a rural area. 
The first stanza describes her hard labor starting from morning till evening. Unlike the speaker in "The Islands of Aran" who touches the crushing waves of the sea, the female character of "Idyll" is not aware of the absurdity of her tedious and boring life which, in effect, makes the whole day more brutal and unbearable. The tragedy is that she is blinded by "A hay's dance and a stub of carrion." Compared to persona's awareness in "Aran" who constantly "stares out the waves" and ready to revolt against the brutal fate, the woman in "Idyll" is blinded by futile attempts to escape the obscure threat which she avoids to stare. Finally, lighted carrion is burned out to ashes, darkening her vision. In that manner, the shortened remnant of the lighted carrion seems to be associated with the adversities of life and death. As we read the poem, it poses a question "What's her life's centered dilemma/... Will give help to the heart's masquerading search?" It is obvious that the women's inquiry is blind and this conceals the reality. She is searching for a love so that she can find tranquility with him, but the lover says that she would not be able to find the help she is seeking for. All her search for help and finding a lover seems to be vague and absurd because the love is also as vague and empty as she herself is. Thus, the lover replies to her search as "Then the web, the well of her lover cries." Here, both the "web" and the "well" imply entrapment and void. The last stanza of the poem reveals more about the empty lovers and the woman's retreat in her confrontation with the experiences and absurdity of life. There is no real communication or sensation between the lovers. Therefore, she takes refuge to the corner of a room instead of confronting the life's experience. The whole poem mirrors the absurd condition the woman is facing and it embodies a sorrowful experience of pity and fear.

"Chandeliers and Shadows" is Pinter's early poem which depicts the concept of death as the root of the absurdity; "enwrapped in this crust", "worlds dying","crumpled mosaic", and"camphor" are images of the poem connected to death. The image of death recurs in different forms in Pinter's canon. "Chandeliers and Shadows"focuses on woman and the interactions between men and women. The poem eventually reveals the poet's persona encouraging the readers towards assertiveness, rage and revolt in the irrational world reminiscent of Sisyphus's condition. The first stanza depicts the absurd condition as a brothel, a room, and a stateroom and it is extended into the mountains, pastures, and different natural images especially negative and unfavorable such as "suns in delirium" and "worlds dying." The overall picture embodies a world view, representing the tone of the whole poem. The concluding effects of the poem through all the unpleasant images communicate a real vision of the absurd existence which most of the people experience. The poem depicts an absurd world in which the eyes of queen "germinate" in a brothel and "the kings are fled." By describing the eyes of the queen, "inseminating" or "sprouting" in a brothel instead of being able to see, the poet attempts to mirror people as the 'escapists' and their refusal to perceive the absurdity of existence. Meanwhile, the poet says "I, foolish, from lunatic spheres.../Will run crazy with lepers/A tardy locust/To plunder and verminate man's pasture entirely." As regards the poet's realization of the suffocating nature of the escape, he has made his mind to act, though such revolt is risky and may result in destruction. Accordingly, the last four lines indicate that the poet is aware of the brutal nature of death and it is this awareness that makes life so absurd andirrational.

Pinter's another early poem which mainly focuses on the concept of absurdity is "EuropeanRevels".It portrays a futile attempt to escape from the realities of life. Here, "Zendalover, the old Serbian Claptrap" escapes from the moment when she is "self-begetting"; it is a time during which she "From adoration strangled her brother." This is all metaphorical, because the "killing" shows her envy towards what she has seen as her brother's power. Thus, she is determined to kill him through rageso as to take control over the situation. Now, her dead brother exhausts her and she escapes from there into "revels" in Europe. Regarding the escapist nature of the experiences of life, all of the men she meets become "plaster lads ...", "summer heavy on her blood's alter." and"wasted in heart." She, meantime, understands that men also seek their own joys and revels as escape; they seem to be "Dribbling loonies" who just "Jug Slav Kinches./... Slum and stem the waxing blood." The resulting image is associated with both the reveling men and Zendalover and other females. It seems that the revels are futile efforts to avoid the absurd reality of life. The poem "European Revel" implies that neither the peaceful attempts to escape in the room nor passionate sexuality can permanently conceal the indications of the absurdity.

"The Midget" is another poem embodying absurdist vision through the image of death. It identifies death as a source of absurdity. This short poem stresses on the idea of death as a focal point. The menacing atmosphere which dominates Pinter's dramatic works also displays itself in this poem. "The Midget" begins with a night, leading the reader into an atmosphere full of menace with "The voyagers stand stiff/stiff and coffined,Death sure/In that still place/tall hats on,Hands clasped." The sense of panic aggravates with an air of absurdity, hopelessness and vulnerability. This menacing atmosphere is reminiscent of Pinter's early plays. He masterfully reveals his absurdist vision in "The Midget," implying that man is born and lives with 'death'. The poet, thus, believes that living humans are as good as dead, since death overshadows the entire life and it approaches as rapidly as possible. The second stanza of the poem in which the voyagers are confined and stand stiff may remind us of Beckett' Waiting for Godot. Meanwhile, the speaker views the midget "Upon the crest" and in the "ringing airs" - an insight which seems to contrast the stiff and coffined voyagers who are really still. The voyagers are stiff since they look to be escapists, and their fear of death dominates their lives only because they do not attempt to experience the reality of existence. The poet implies that they stand stiff because they fear to confront the "wind." This fear of death and the lack of courage to 'revolt' make the voyagers retreat to their coffins earlier than expected.

Pinter has always tried to show his denial of violence but continually attempted to encourage his characters to resist while facing upto the powerful forces and the fear of death. The coffin and the way people are dressed formally in "The Midget" resembles Stanley's condition in The Birthday Party in which he retreats while confronting the realities of life. 
What matters here is that the midget at least has the courage to challenge the "ringing airs" and the "night wind", while Stanley mostlyevades facing up the experience. Here, Pinter employs the "night wind" in the same way he uses "the pounding waves" of the sea in "The Islands of Aran," to allegorically indicate the experience man confronts in his life. The midget's confrontation with night wind signifies the possibility of the absurd man living on the peak; it also suggests the poet's view that man can resist and revolt instead of retreating from the challenge while he is aware of his own absurd condition.

\section{CONCLUSION}

This study attempted to examine Pinter's early poetry to track the absurdist voices and the existential predicaments man faces in his life. The discussion explored that his early poems draw attention to the prevailing characteristics and images of the twentieth century literature mainly known as the 'literature of the absurd'. All these poems depict a sort of alienation, identity, pessimism and existential dilemma. This paper illustrated how individuals react differently in their confrontation with the absurdity of life. It also displayed how some people may succeed to overcome such absurdity and some may fail to do so. Like Camus, Pinter admires those individuals who challenge the absurd condition of life as Sisyphus does. This research also presented Pinter as a practitioner of the absurd literature who depictsthe way different people live and think in an absurd condition. Pinter has endeavored to communicate a world view regarding man's confrontation with the absurdity. In his absurdist poetry, Pinter depicts various sorts of the absurdity. The study showed that in some of these poems man, while unaware of the absurd, surrenders himself to the crushing fate and rejects to face up the hardship of life. Some of these absurdpoems depict men who do not resign in their confrontation with challenges while they are fully aware of the absurdity. "The Midget" and "The Islands of Aran" suggest such world view.

Another claim made by the currentresearch is the demonstration of the absurdist vision of Pinter's early poems and its expansion in his early dramatic works. Therefore, the researcher believes the appreciation of his absurdist poems in this study will provide the scholars and critics with crucial background towards a better understanding of his plays.

\section{REFERENCES}

Arcilla, RENÉ V. Mediumism: A Philosophical Reconstruction of Modernism for Existential Learning. New York: State University of New York Press. 2011. Print.

Arrandale, Richard. "Drama, Film and Post Modernity," TheBlackwell Companion to Modern Theology. Gareth Jones (ed.) London: Blackwell Publishing Ltd., 2007. Print

Baker, William, and Stephen Ely Tabachnick.Harold Pinter. Modern Writer Series. New York: Barnes and Noble, 1990. Print.

Billington, Michael. The Life and Work of Pinter. London: Faber and Faber, 2007. Print.

---. "Pinter's Early Poems." http://www.haroldpinter.org/. Web.16. Feb.2013.

Camus, Albert. The Myth of Sisyphus and Other Essays. Translated by Justin O'Brien. London: Hamish Hamilton, 1991. Print.

Esslin, Martin. Pinter: A Study of His Plays. London: Methuen, 1977. Print.

---. The Theatre of the Absurd. New York: Anchor Books, 1961. Print.

Gale, Steven H. Butter's Going Up. Durham: Duke University Press, 1977. Print.

Gussow, Mel. Conversation with Pinter. New York: Limelight, 1994. Print.

Hynes, Joseph. "Pinter and Morality."The Virginia Quarterly Review.10 August 2008. Web.28 Oct 2013.

Merritt, Susan Hollis. Pinter in Play: Critical Strategies and the Plays of Harold Pinter. Durham: Duke Univ. Press, 1995. 137. Print.

Pinter, Harold. Poems and Prose1949-1977. London: Eyre Methuen Ltd. 1978. Print.

Prentice, Penelope.The Pinter Ethic: The Erotic Aesthetic. New York: Garland Publishing Inc., 2000. Print.

Rodriguez, Deanna. "The Absurdity of Suicide".New Academia.Vol. II Issue IV, Oct. 2013.Web. Feb. 3014

Roy, Emily. British Drama since Shaw. Illinois: S. Illinois U. Press. 2005. Print.

Thorne, Sara. Mastering Poetry. New York: Palgrave Macmillan. 2009. Print. 